\title{
Field evidence of UK wild bird exposure to fludioxonil and extrapolation to other pesticides used as seed treatments
}

\author{
Cannelle Tassin de Montaigu ${ }^{1}$ (1) $\cdot$ Dave Goulson $^{1}$
}

Received: 10 June 2021 / Accepted: 13 October 2021 / Published online: 15 November 2021

(c) The Author(s) 2021

\begin{abstract}
We determine the exposure of wild birds to pesticides via consumption of fludioxonil-treated winter wheat seeds following autumn drilling. We recorded the density of seeds left on the soil surface, bird density, and consumption of pesticide-treated seed by birds using camera traps. We calculated the dose ingested by each bird species in a single feeding bout and if they ate treated seeds exclusively for 1 day. We extrapolated this for an additional 19 pesticides commonly used as seed treatments, assuming equal consumption rates. All three fields contained grains on the soil surface (mean $7.14 \mathrm{seeds} / \mathrm{m}^{2}$ on sowing day). In total, 1,374 granivorous birds spanning 18 different species were observed in the fields, with 11 species filmed eating the seeds. Fludioxonil appears to pose a low risk to birds, with $<1.14 \%$ of the LD50 potentially ingested by a bird for a daily maximum amount of seeds. Analysis of the further 19 pesticides commonly used as seed dressings suggests that the neonicotinoid insecticides imidacloprid, clothianidin, and thiamethoxam represent the highest risk for granivorous birds. For example, chaffinch (Fringilla coelebs) could consume 63\% of LD50 of imidacloprid in a single feeding bout, and $370 \%$ in a day. Further investigation is clearly required to determine whether seeds treated with these other pesticides are consumed as readily as those treated with fludioxonil, as if so this is likely to cause significant harm.
\end{abstract}

Keywords Pesticide $\cdot$ Seed treatment $\cdot$ Bird $\cdot$ Farmland $\cdot$ Fungicide $\cdot$ LD50

\section{Introduction}

The application of pesticides on crops has been perceived as one of the drivers of the decline of farmland bird populations (Chamberlain 2002; Hallmann et al. 2014). Pesticide usage can negatively affect avian population through direct toxicity; altering survival, health, and/or reproduction; and indirect pathways such as food reduction and habitat degradation and loss (Geiger et al. 2010; Hallmann et al. 2014; Potts and Aebischer 1995; Wilson et al. 1999; Watkinson et al. 2000).

Pesticide-coated seeds provide a convenient method for pesticide application on crops as they decrease the need to spray, reduce the exposure to the farmer, deposit the active substance on a smaller area, and, in theory at least, decrease the risk posed to non-target species (Dewar and Asher 1994;

Responsible Editor: Philippe Garrigues

Cannelle Tassin de Montaigu

ct430@sussex.ac.uk

1 School of Life Sciences, University of Sussex, Falmer, East Sussex, UK
Hart and Clook 1994). However, some seeds are not buried during sowing, remain on the soil surface, and are thus available to granivorous vertebrates (Goulson 2013). De Snoo and Luttik (2004) found that the type of crop, soil condition, sowing technique, location on the field, and season all influence greatly the percentage of seeds that remain available on the soil surface, which is typically between 0.5 and $9.2 \%$. They found an important difference between the autumn and spring, with the abundance of seeds on the surface in autumn higher by a factor of 13 (probably due to harder soil conditions), and 3.5 times higher on the headlands than in the centre of fields.

When winter cereal sowing became common, winter cereal crops became a key component in the diet of many granivorous birds (Browne and Aebischer 2003; Robinson 2004; Perkins et al. 2007). For example, the digestive contents of red-legged partridge (Alectoris rufa) were analysed during the cereal sowing season in Spain and Lopez-Antia et al. (2016) found that cereal seeds represented up to $89.3 \%$ of the consumed biomass. Since seeds are commonly coated with pesticides, this provides a route of exposure of birds (Lopez-Antia et al. 2016; Holland et al. 2006). Numerous 
studies have shown exposure or poisoning incidents involving a variety of bird species consuming seeds treated with neonicotinoids, pyrethroids, organochlorines, organophosphates, or carbamates (Murton and Visozo 1963; Porter 1977; De Snoo et al. 1999; Millot et al. 2017; Corcellas et al. 2017; MacDonald et al. 2018; Lennon et al. 2020b).

The dose ingested by birds in a single feeding bout on treated seeds can be sufficient to cause lethal and sublethal effects (Prosser and Hart 2005). Even if less acutely toxic to avian species, fungicides are applied in greater quantities than insecticides (Tassin de Montaigu and Goulson 2020) and could represent a risk to birds. Mateo et al. (2016) estimated, using daily food intake, that the fungicides thiram and tebuconazole could represent a risk to red-breasted geese (Branta ruficollis). Experimental studies have shown that exposure to triazole fungicides used in seed coating treatments can affect reproduction in Japanese quail (Coturnix japonica) by disturbing testicular histology and sperm production (Grote et al. 2008). Similarly, exposure to seeds treated with the fungicide difenoconazole was found to reduce the reproductive success of the red-legged partridge by reducing the fertility rate of eggs (Lopez-Antia et al. 2013). More recently, Lopez-Antia et al. (2018) also found a 56-62\% brood size reduction in partridge feeding on seeds treated with the fungicide flutriafol, even when doses were below the recommended application rates.

Although consumption of treated seeds would seem to be a source of significant exposure of granivorous birds to a range of different pesticides, our knowledge on wild bird exposure to pesticides via this route is still sparse. We have limited data as to which species consume treated seeds, and on their consumption rates especially when it comes to pesticides other than insecticides (Prosser and Hart 2005; Lopez-Antia et al. 2016; Millot et al. 2017; Lennon et al. 2020a). This study aims to investigate which bird species feeds on pesticide-coated wheat seeds during winter cereal sowing season in the UK, and to quantify the exposure of different wild bird species to seeds coated with the fungicide fludioxonil. Additionally, we extrapolated these findings to an additional 19 pesticides that are commonly used as seed treatment worldwide, to obtain a more general understanding of the potential risks to birds associated with current seed treatments.

\section{Material and methods}

Methods were based on a previous study by Lennon et al. (2020a) which focussed on exposure to clothianidin, a neonicotinoid insecticide, during the autumn sowing season. We collected data from three fields on two farms located in East Sussex, UK, during the autumn sowing seasons of 2020 (Hartfield: $51.1023^{\circ} \mathrm{N}, 0.1115^{\circ} \mathrm{E}$; Barnham: $50.8278^{\circ} \mathrm{N}$, $\left.0.6357^{\circ} \mathrm{W}\right)$. The fields were sown with fludioxonil-dressed wheat seeds (respectively Beret Gold ${ }^{\circledR}$ and Vibrance DUO®; Syngenta, UK; max application rate of $2 \mathrm{~L} /$ tonne of seed). Farmers continued their standard practice, seed coating preparation, and sowing methods throughout the season and they were aware that researchers would be surveying their fields. Table 1 gives full details on the farms and field characteristics. All data collection was conducted by the same observer.

\section{Surface seed density and seed cluster counts}

On days $0,1,3,6,9$, and 12 (day 0 being within $24 \mathrm{~h}$ of drilling), the number of treated wheat seeds visible on the ground surface, along transects bisecting the headlands and field centre, was recorded in 60 quadrats $\left(0.25 \mathrm{~m}^{2}\right), 20$ quadrats in the field centre and 20 quadrats at each of the two field headlands, at least $5 \mathrm{~m}$ apart (spacing of the quadrats was bigger on larger fields). In addition, on the day that seeds were drilled (day 0) in each field, the observer walked along the field boundary and counted seed clusters, defined as a spillage if there were $>10$ seeds within a $0.25-\mathrm{m}^{2}$ area. Clusters of $>100$ seeds were also noted (Table 1).

\section{Surveys of bird abundance and bird density}

On days $0,1,3,6,9$, and 12, bird abundance was measured in two manners:

First, when arriving on site, a scan of all species present on the entire field was completed by using binoculars. Second, a flush count was conducted whilst walking field transects (a maximum of three transects per field separated by at least $100 \mathrm{~m}$, following Lennon et al. 2020a). The location of each bird was recorded (field boundaries, centre, or both) and, when possible, species were identified. For statistical analysis, the abundance of only seed-eating birds was used, which excluded the common buzzard (Buteo buteo), house martins (Delichon urbicum), kittiwakes (Rissa tridactyla), and herring gulls (Larus argentatus). Additionally, for statistical analysis, bird density (birds/ha) for each of the fields was used.

\section{Camera trapping to quantify seed consumption}

Two Camera traps (Bushnell Natureview Cam Essential HD, USA) were installed on day 0 in each field. One camera was placed in the centre of the field and the second on the field boundary. A maximum of $200 \mathrm{~g}$ of seeds (approx. 3,000 seeds) obtained from the farmer were placed approximately $2 \mathrm{~m}$ in front of the camera. The cameras remained active until seeds were depleted or for no longer than 20 days. Cameras recorded for 10 continuous seconds when activated by movement. The time spent in front of the camera and the 


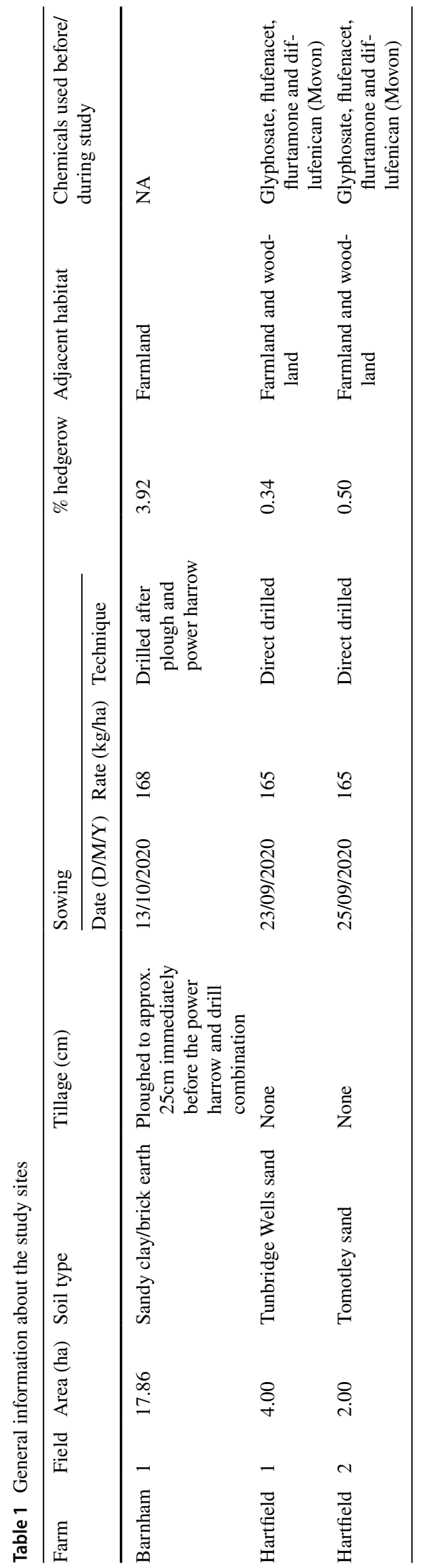

number of treated seeds ingested (or seed intake) by each individual were counted. Treated seeds were commercially coloured with a bright red dye and thus easily recognised in the footage. Two consecutive feeding bouts by birds of the same species were counted as two different individuals except when the interval was less than $5 \mathrm{~s}$ and the observer was confident that it was the same individual, based on its position in the field of view. This approach will tend to lead to a conservative estimate of seed consumption per bird.

\section{Estimation of the percentage of LD50 ingested}

Firstly, we estimated the LD50 (mg/bird) (the dose of substance that gives a $50 \%$ probability of death), for each species observed feeding on treated seeds using scaling factors based on weight (Mineau et al. 1996, 2001; Tassin de Montaigu and Goulson 2020). For the five insecticides and 15 fungicides that are frequently used as seed treatment (in Europe, North America, and/or Asia), the LD50 (mg/kg of body weight) was obtained from the Pesticides Properties DataBase (PPDB University of Hertfordshire). The maximum application rates recommended by manufacturers were available on the seed treatment labels. Note that some of these chemicals, such as neonicotinoid insecticides, are now banned from use as seed dressings in Europe but are widely used elsewhere in the world, and even within Europe, individual countries often grant temporary derogations to allow their use as seed dressings.

Secondly, we calculated the quantity of pesticide coating on seeds and the corresponding quantity ingested by species according to their maximum seed intake (maximum number of seeds consumed per species) in a feeding bout. For instance, both Beret gold® and Vibrance DUO® had a concentration of fludioxonil of $25 \mathrm{~g} / \mathrm{L}$ and the labels recommended a maximum dose of $2 \mathrm{~L} /$ tonne of seed. This corresponds to a maximum of $50 \mathrm{~g}$ fludioxonil/tonne of seed or $0.05 \mathrm{~g}$ of fludioxonil $/ \mathrm{kg}$ of seed. As an example, we observed ring-necked pheasants (Phasianus colchicus) consumed a maximum of 301 seeds in a foraging bout. The average weight of one wheat seed was taken to be $0.045 \mathrm{~g}$ (Bouaziz and Hicks 1990). Therefore, the maximum weight of seeds consumed for the pheasant is $13.5 \mathrm{~g}$. We can then calculate the quantity of fludioxonil consumed by the pheasant for its maximum intake, which is $0.677 \mathrm{mg}$ for 301 seeds.

Thirdly, we calculated the corresponding percentage of LD50 consumed by the birds. For example, the fludioxonil LD50 for pheasant is about $2,680 \mathrm{mg} / \mathrm{bird}$; the mass of fludioxonil consumed by the pheasant in 301 seeds being 0.677 $\mathrm{mg}$, the corresponding percentage of LD50 consumed by pheasants for 301 seeds is $0.025 \%$.

Furthermore, Crocker et al. (2002) found a method estimating the mean daily food intake ( $\mathrm{g}$ ) for different food types (e.g. cereal, arthropods, dicot crop leaves) for various bird 
and mammal species based on daily energy expenditure. We used the mean food intake they found for 'cereal' and 'weed seed' for some of the species we observed, and we similarly calculated what a total daily intake of treated seed would represent as a percentage of LD50 consumed.

Since all species swallowed the seeds whole except the common chaffinch (Fringilla coelebs) which de-husked seeds, we assumed a worst-case scenario with no de-husking and maximum exposure of the seed dressing.

\section{Statistical analysis}

All analyses were performed using R v. 4.0.3 (R Core Team 2020). We used general linear models (GLMs) using the package 'Ime4' (Bates et al. 2015) with significance level set at 0.05 , with temperature $\left({ }^{\circ} \mathrm{C}\right)$, cloud cover $(\%)$, rainfall $(\mathrm{mm})$, and wind $(\mathrm{km} / \mathrm{h})$ as random factors, and field as a fixed factor to investigate the relationship between surface seed density, days post-sowing, location on field (headland or centre), and bird density. Except for surface seed density where a Gaussian distribution was used, all GLMs were run using a negative binomial distribution to account for overdispersion. Three separate models were fitted, (a) seed density (seeds $/ \mathrm{m}^{2}$ ) as a function of days post-sowing, the mean surface seed density was calculated per field; (b) bird density (birds/ha) as a function of days post-sowing; (c) bird density as a function of seed density. We also compared the average seed consumption (number of seeds consumed per feeding bout) according to camera location on the fields (centre field or boundary).

\section{Results}

\section{Seed and bird density}

A total of 60 clusters of over 10 seeds and 14 clusters of over 100 seeds were counted along the field boundaries of Barnham farm, 69 clusters of 10 seeds and 11 clusters of over 100 seeds were counted along the field boundaries of Hartfield field 1, and 30 clusters over 10 seeds and 5 clusters over 100 seeds were counted along the field boundaries of Hartfield field 2. This represents for Barnham farm a minimum of 2000 seeds, for Hatfield field 1 a minimum of 1790 seeds, and for Hartfield field 2 a minimum of 850 seeds available on the soil surface just from those clusters.

Over all fields, the seed density ranged from 0 to 124 seeds $/ \mathrm{m}^{2}$ with an average surface seed density of 7.14 seeds/ $\mathrm{m}^{2}$ on day 0 , more specifically 9.7 seeds $/ \mathrm{m}^{2}$ on Barnham farm and 5.87 seeds $/ \mathrm{m}^{2}$ for Hartfield farm. This average surface seed density significantly decreased on all fields over time $\left(t_{35}=-3.87, p<0.001\right)$. After 4 days (from day 0 to day 3 post-sowing), Barnham farm average surface seed density had decreased by $98.6 \%$, Hartfield field 1 decreased by $77.61 \%$, and Hartfield field 2 decreased by $66.75 \%$ (Fig. 1).

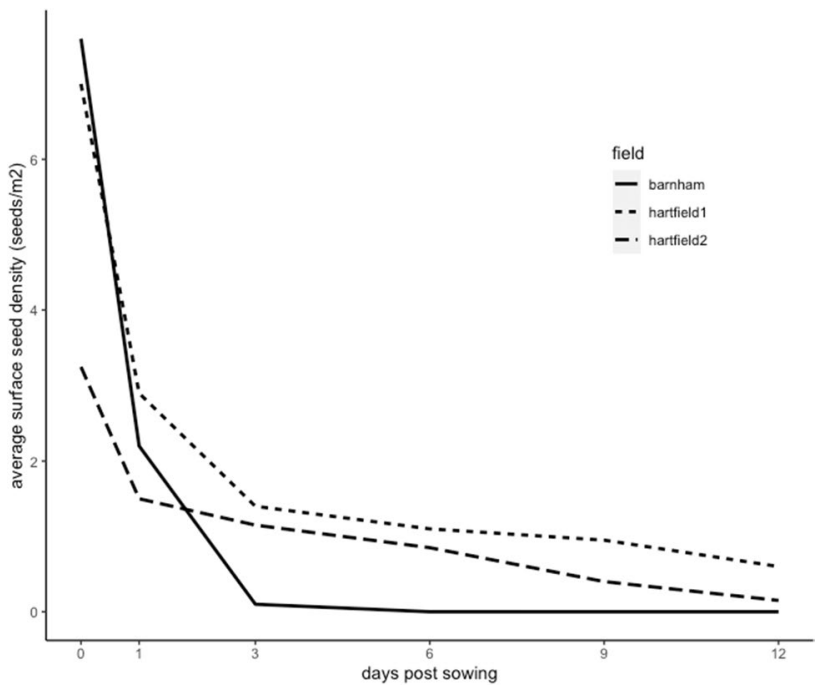

Fig. 1 Seed density according to the days post-sowing for the different fields

The average surface seed density on headlands (2.77 seeds $/ \mathrm{m}^{2}$ ) was 4 times higher than the average surface seed density found in the centre of fields $\left(0.68\right.$ seeds $\left./ \mathrm{m}^{2}\right)$ for all days post-sowing $\left(t_{35}=3.045, p<0.01\right.$; Fig. 2 ).

Across all fields, we observed a total of 1,374 individual seed-eating birds distributed across 18 species, plus 88 unidentified individuals (too far away or too fast for the observer to be certain of the species; supplementary material, Table 1). For the different bird abundance recordings, a mean count over all fields of 11.2 granivorous birds on arrival and 8.13 granivorous birds along transects suggested that the presence of the observer lowered the number of birds present on site. Barnham field showed the highest seed-eating bird abundance with 1,006 birds observed

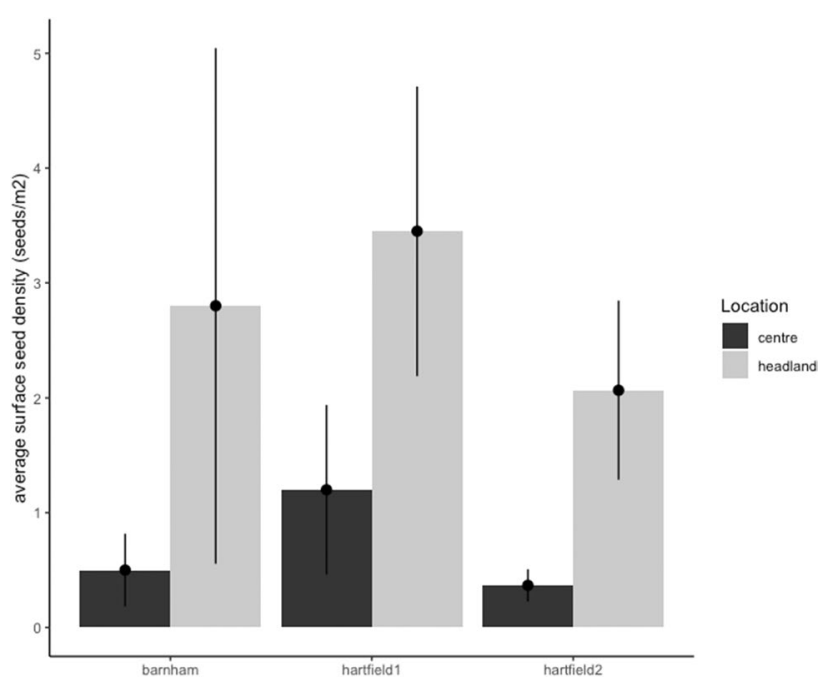

Fig. 2 Seed density according to location on field for all fields 
during the study, compared to 283 birds for Hartfield field 1 and 85 birds for Hartfield field 2. In terms of density of birds, this represents 560 birds/ha for Barnham field, compared to 70.8 birds/ha for Hartfield field 1 and 42.5 birds/ ha for Hartfield field 2. The bird density (granivorous birds per hectare) tended to decrease with days post-sowing $\left(t_{17}=\right.$ $-0.996, p=0.34)$, but this was explained only by Barnham farm for which the total bird density significantly dropped by $88.4 \%$ between day 0 and day 12 post-sowing $\left(t_{5}=-4.22\right.$, $p=0.01$; Fig. 3). Similarly, a positive relationship between average surface seed density and bird density was much stronger at Barnham $\left(t_{5}=4.130, p=0.01\right)$ than across all three fields $\left(t_{17}=1.957, p=0.07\right.$; Fig. 4$)$.

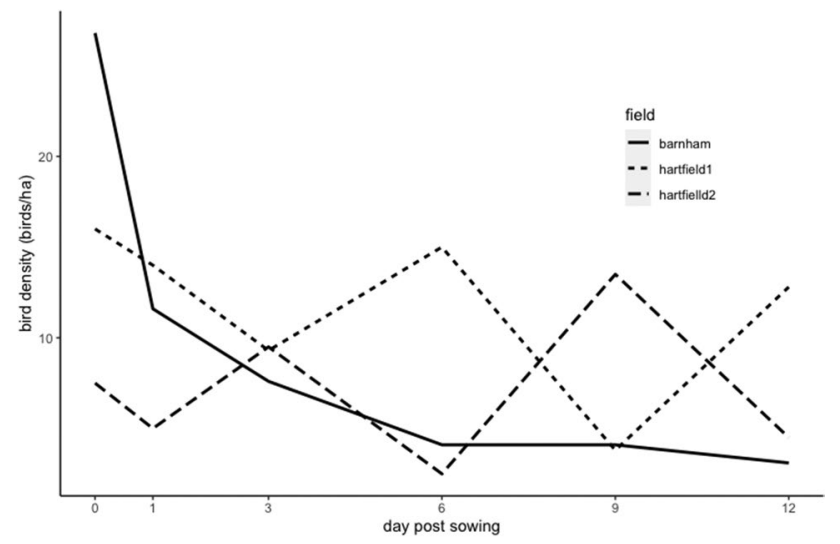

Fig. 3 Total bird density (birds per hectare) according to day postsowing for the different fields

\section{Seed consumption}

On the camera footage, we observed 11 different bird species eating the wheat seeds across the three fields (supplementary material, Table 1). The carrion crow (Corvus corone), common chaffinch, ring-necked pheasant, red-legged partridge, and rook (Corvus frugilegus) were the five bird species observed most. Between them, carrion crow and common chaffinch comprised more than half of all recordings $(27.8 \%$ and $22.8 \%$ of observations, respectively) although both were observed exclusively on Barnham farm. The seed consumption recorded per observation ranged from 1 to 405 seeds with an average across species of 21.1 seeds. The bird that consumed the most seeds per feeding bout was a feral pigeon (Columba livia domesticus) with 405 seeds consumed in 5 min and $30 \mathrm{~s}$, corresponding to $10.9 \%$ of the species' average body weight. The highest average consumption rate of seeds happened on the boundary cameras, and some species were only observed on field boundaries, for example the Eurasian magpie (Pica pica) and the feral pigeon.

\section{Estimation of the percentage of LD50 ingested}

Of the 20 most used pesticides as seed treatments, the insecticides imidacloprid, clothianidin, and thiamethoxam present the highest risk of birds, based on the percentage of LD50 ingested in a single feeding bout $(63.23 \%, 6.44 \%$, and $4.33 \%$ for the chaffinch and $56.90 \%, 5.80 \%$, and $3.89 \%$ for the feral pigeon, respectively, Table 2). The fungicide carboxin and the insecticide tefluthrin also appear to pose some risk, providing $3.61 \%$ and $3.91 \%$ of the LD50 for chaffinch
Fig. 4 Bird density (birds per hectare) according to seed density (seeds per square metre) for the different fields. The shaded band shows the $95 \%$ confidence interval on the fitted values
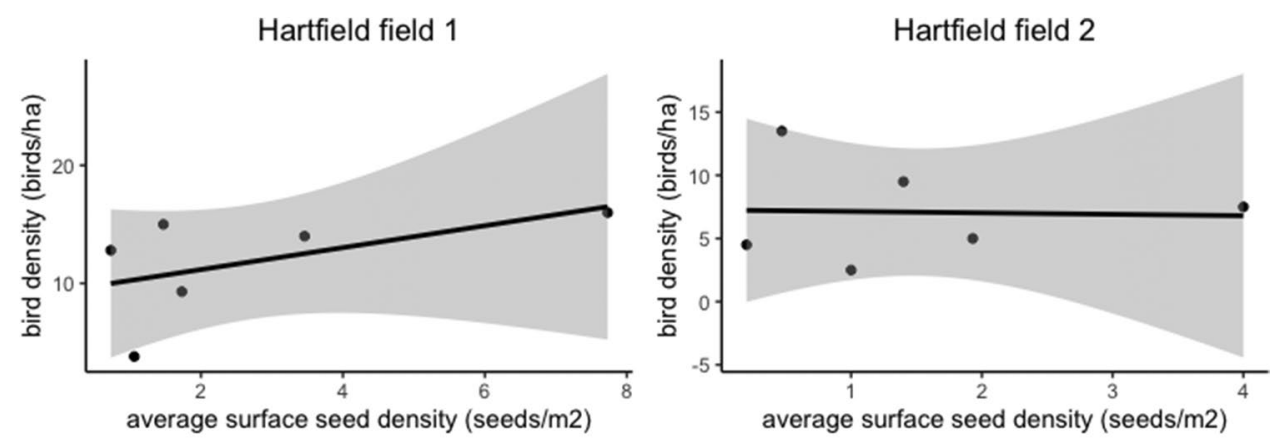

Barnham

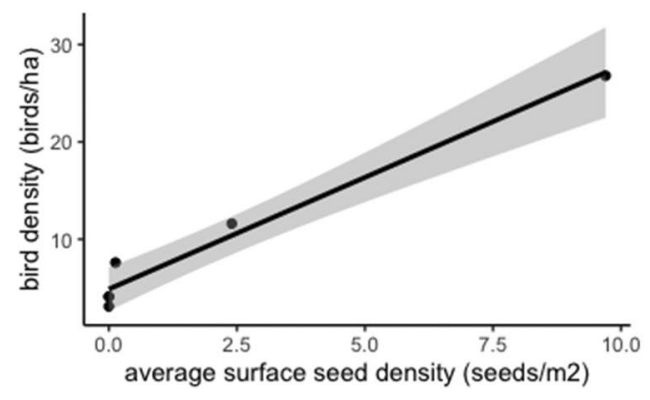


and $3.25 \%$ and $3.51 \%$ for the feral pigeon, respectively. Fludioxonil, which was the active ingredient used as the seed treatment on both farms, represented $0.19 \%$ of the LD50 ingested by chaffinch and $0.17 \%$ of the LD50 ingested by feral pigeon. The rest of the pesticides listed in our analysis appear to provide little to no threat to birds via this source of exposure.

As one might expect, the patterns are broadly similar if we examine the doses consumed if we assume that birds fed only treated seeds all day. Imidacloprid (370\%), clothianidin $(37.8 \%)$, and thiamethoxam $(25.3 \%)$ again presented the highest percentage of LD50 ingested for chaffinch, followed by carboxin (21.2\%) and tefluthrin (22.9\%, Table 3).

Comparing bird species in our study, chaffinch appears to be the species most likely to receive a harmful dose of pesticide from seed-treated grain, followed by feral pigeon, European robin (Erithacus rubecula), wood pigeon (Columba palumbus), and woodlark (Lullula arborea; Table 2). When looking at the species occurrence between field observation and camera footage, we found that some species, such as skylarks (Alauda arvensis) or house sparrows (Passer domesticus), never appeared in front of the camera but were observed on the field (supplementary material, Table 1 ). Therefore, we cannot exclude the consumption of treated seeds by these farmland species.

\section{Discussion}

Considerable numbers of seeds were left on the soil surface after sowing, with an average of 7.14 uncovered seeds per square metre across all fields on day 0 , without clusters. This represents 71,400 seeds per hectare, which would constitute nearly 1.3 million surface seeds for a field like Barnham. The seed density was higher on Barnham farm $\left(9.7\right.$ seeds $\left./ \mathrm{m}^{2}\right)$ than on Hartfield farm (5.87 seeds/ $\mathrm{m}^{2}$ ). Studies tend to show that the seed depth is the main driver of seed availability on the soil surface and that the variance that exists is largely due to soil condition (Pascual et al. 1999a; De Snoo and Luttik 2004). Therefore, the difference of surface seed density between farms could be due to the soil variation more than the use of plough and harrow before drilling. Overall, the surface seed density was higher on the headlands than on the centre for all fields (Fig. 2). Often, the drilling equipment is less effective at the end of the seed line (headlands) and, a small area, where headlands and centre field overlap, is often drilled twice (De Snoo and Luttik 2004; McGee et al. 2018; Roy et al. 2019; Lennon et al. 2020a).

The seed density significantly decreased with time (days post-sowing) on all fields and this decrease was the highest during the first 3 days post-sowing (Fig. 1). Our analysis showed a significant positive relationship between total bird density and the average surface seed density for

Table 2 LD50 and percentage of LD50 consumed by the 11 species from our camera trap study in a single feeding bout, for the 20 most used pesticide seed treatments. The dark to light grey gradient indicates the highest to lowest percentage of LD50 consumed

\begin{tabular}{|c|c|c|c|c|c|c|c|c|c|c|c|}
\hline Species & Feral pigeon & Ring-necked pheasant & Wood pigeon & Red-legged partridge & Carrion crow & Rook & Common chaffinch & Eurasian magpie & European robin & woodlark & Western jackdaw \\
\hline Latin name & Coum bia liva domesticus & Phasianus colchious & Columba paumbus & Alectoris ruta & Convs corrane & Convus frugitegus & Fringilla coelebs & Pica pica & Entithaus rubecula & Lulula arborea & corvus monedula \\
\hline carboxin LDSO (mglbira) & 560.33 & 2881.83 & 738.78 & 1495.34 & 1460.46 & 862.71 & 27.39 & 474.89 & 19.56 & 42.61 & 599.4 \\
\hline carboxin consumed (\% of LD50) & 325 & 0.47 & 1.36 & 0.3 & 0.3 & 0.25 & 3.61 & 0.17 & 1.61 & 0.63 & 0.03 \\
\hline clothianidin LD50 & 112.07 & 576.37 & 147.76 & 299.07 & 292.09 & 172.54 & 5.48 & 94.98 & 3.91 & 8.52 & 117.9 \\
\hline elothianidin consumed & 5.8 & 0.84 & 2.42 & 0.54 & 0.54 & 0.45 & 6.44 & 0.3 & 2.87 & 1.13 & 0.1 \\
\hline cypermethrin LDSO & 1451.89 & 7467.22 & 1914.28 & 3874.63 & 3784.26 & 2235.4 & 70.97 & 1230.5 & 50.67 & 110.41 & 1627.2 \\
\hline cypermettrin consumed & 0.75 & 0.11 & 0.31 & 0.07 & 0.07 & 0.06 & 0.84 & 0.04 & 0.37 & 0.15 & 0.01 \\
\hline oifeconazole LD50 & 327.9 & 1686.4 & 432.32 & 875.05 & 854.64 & 504.84 & 16.03 & 27.9 & 11.44 & 24.93 & 344.9 \\
\hline difenoconazole consumed & 0.28 & 0.04 & 0.12 & 0.03 & 0.03 & 0.02 & 0.31 & 0.01 & 0.14 & 0.05 & 0.03 \\
\hline fudxonil LO50 & 521.24 & 2680.77 & 687.24 & 1391.01 & 1358.57 & 802.52 & 25.48 & 441.76 & 18.19 & 39.64 & 548.3 \\
\hline fllucioxonil consumed & 0.17 & 0.03 & 0.07 & 0.02 & 0.02 & 0.01 & 0.19 & 0.01 & 0.09 & 0.03 & 0.02 \\
\hline futriatol LDSO & 122.34 & 629.19 & 161.3 & 326.48 & 318.87 & 188.36 & 5.98 & 103.68 & 4.27 & 9.3 & 128.7 \\
\hline flutriafol consumed & 0.37 & 0.05 & 0.16 & 0.03 & 0.03 & 0.03 & 0.41 & 0.02 & 0.18 & 0.07 & 0.07 \\
\hline fluxaapyroxad LD50 & 521.24 & 2680.77 & 687.24 & 1391.01 & 1358.57 & 802.52 & 25.48 & 441.76 & 18.19 & 39.64 & 548.3 \\
\hline fluxapyroxad consumed & 0.09 & 0.01 & 0.04 & 0.01 & 0.01 & 0.01 & 0.1 & 0 & 0.04 & 0.02 & 0.02 \\
\hline imidacloprid LD50 & 9.41 & 48.37 & 12.4 & 25.1 & 24.51 & 14.48 & 0.46 & 7.97 & 0.33 & 0.72 & 9.9 \\
\hline imidacloprid consumed & 56.9 & 8.22 & 23.76 & 5.32 & 5.28 & 4.38 & 69.23 & 2.98 & 28.18 & 11.09 & 1.18 \\
\hline ipconazole LD50 & 250.71 & 1289.45 & 330.56 & 669.08 & 653.47 & 386.01 & 12.26 & 212.48 & 8.75 & 19.07 & 212.5 \\
\hline Ipconazole consumed & 0.15 & 0.02 & 0.06 & 0.01 & 0.01 & 0.01 & 0.16 & 0.01 & 0.07 & 0.03 & 0.04 \\
\hline metalaxyI LDSO & 223.58 & 1149.89 & 294.78 & 596.66 & 582.74 & 344.23 & 10.93 & 189.49 & 7.8 & 17 & 235.2 \\
\hline metalaxyl consumed & 0.02 & 0 & 0.01 & 0 & 0 & 0 & 0.03 & 0 & 0.01 & 0 & 0 \\
\hline penflutuen LS50 & 1042.47 & 5361.54 & 1374.47 & 2782.02 & 2717.13 & 1605.04 & 50.96 & 883.51 & 36.38 & 79.27 & 1096.6 \\
\hline penffuten consumed & 0.17 & 0.03 & 0.07 & 0.02 & 0.02 & 0.01 & 0.19 & 0.01 & 0.09 & 0.03 & 0.01 \\
\hline prothiconazole L50 & 521.24 & 2680.77 & 687.24 & 1399.01 & 1358.57 & 802.52 & 25.48 & 441.76 & 18.19 & 39.64 & 548.3. \\
\hline prothioconazole consumed & 0.04 & 0.01 & 0.01 & 0 & 0 & 0 & 0.04 & 0 & 0.02 & 0.01 & 0 \\
\hline pyraclostrobin LDSO & 521.24 & 2680.77 & 687.24 & 1391.01 & 1358.57 & 802.52 & 25.48 & 441.76 & 18.19 & 39.64 & 548.3 \\
\hline pyraclostrobin consumed & 0.36 & 0.05 & 0.15 & 0.03 & 0.03 & 0.03 & 0.4 & 0.02 & 0.18 & 0.07 & 0.02 \\
\hline sedaxane LD50 & 278.34 & 1431.53 & 366.98 & 742.8 & 725.47 & 428.54 & 13.61 & 235.9 & 9.71 & 21.17 & 292.8 \\
\hline sedaxane consumed & 0.33 & 0.05 & 0.14 & 0.03 & 0.03 & 0.03 & 0.36 & 0.02 & 0.16 & 0.06 & 0.03 \\
\hline sittriotam LD50 & 586.39 & 3015.86 & 773.14 & 1564.89 & 1528.39 & 902.83 & 28.66 & 496.98 & 20.46 & 44.59 & 616.8 \\
\hline silthiofam consumed & 0.78 & 0.11 & 0.32 & 0.07 & 0.07 & 0.06 & 0.96 & 0.04 & 0.38 & 0.15 & 0.02 \\
\hline tebuconazole LD50 & 518.11 & 2664.68 & 683.11 & 1382.66 & 1350.41 & 797.7 & 25.33 & 439.11 & 18.08 & 39.4 & 545 \\
\hline tebuconazole consumed & 0.05 & 0.01 & 0.02 & 0 & 0 & 0 & 0.05 & 0 & 0.02 & 0.01 & 0.02 \\
\hline teflutrrin LD50 & 103.72 & 533.44 & 136.75 & 276.79 & 270.34 & 159.69 & 5.07 & 87.9 & 3.62 & 7.89 & 109.1 \\
\hline tefluthrin consumed & 3.51 & 0.51 & 1.47 & 0.33 & 0.33 & 0.27 & 3.91 & 0.18 & 1.74 & 0.68 & 0.1 \\
\hline thiamethoxam L050 & 87.85 & 451.8 & 115.82 & 234.43 & 228.96 & 135.25 & 4.29 & 74.45 & 3.07 & 6.68 & 92.4 \\
\hline thiamethoxam consumed & 3.89 & 0.56 & 1.63 & 0.36 & 0.36 & 0.3 & 4.33 & 0.2 & 1.93 & 0.76 & 0.12 \\
\hline thiram LD50 & 242.37 & 1246.56 & 319.56 & 646.82 & 631.73 & 373.17 & 11.85 & 205.42 & 8.46 & 18.43 & 254.9 \\
\hline thiram consumed & 0.75 & 0.11 & 0.31 & 0.07 & 0.07 & 0.06 & 0.84 & 0.04 & 0.37 & 0.15 & 0.01 \\
\hline triticonazole LD50 & 521.24 & 2600.77 & 687.24 & 1391.01 & 1358.57 & 802.52 & 25.48 & 441.76 & 18.19 & 39.64 & 548.3 \\
\hline triticonazole consumed & 0.17 & 0.03 & 0.07 & 0.02 & 0.02 & 0.01 & & 0.01 & 0.09 & 0.03 & 0.02 \\
\hline
\end{tabular}


Table 3 Percentage of LD50 consumed by species if pesticide-coated seeds correspond to the daily intake, for the 20 most used pesticide seed treatments. The maximum recommended application rate $(\mathrm{g} / \mathrm{kg}$ of seeds) by the companies is provided in the last column. The dark to

\begin{tabular}{|c|c|c|c|c|c|c|c|}
\hline Species & $\begin{array}{l}\text { Ring-necked } \\
\text { pheasant }\end{array}$ & Wood pigeon & $\begin{array}{l}\text { Red-legged } \\
\text { partridge }\end{array}$ & $\begin{array}{l}\text { Carrion } \\
\text { crow }\end{array}$ & Rook & $\begin{array}{l}\text { Common } \\
\text { chaffinch }\end{array}$ & $\begin{array}{l}\text { application rate ( } \mathrm{g} / \mathrm{kg} \text { of } \\
\text { seed) }\end{array}$ \\
\hline Latin name & Phasianus colchicus & $\begin{array}{l}\text { Columba } \\
\text { palumbus }\end{array}$ & Alectoris rufa & $\begin{array}{l}\text { Corvus } \\
\text { corone }\end{array}$ & $\begin{array}{l}\text { Corvus } \\
\text { frugilegus }\end{array}$ & Fringilla coelebs & \\
\hline estimated daily seed intake $(\mathrm{g})$ & 102.70 & 53.10 & 50.60 & 162.20 & 67.50 & 5.80 & _- \\
\hline $\begin{array}{l}\text { carboxin consumed (\% of } \\
\text { LD50) }\end{array}$ & 3.56 & 7.19 & 3.38 & 11.11 & 7.82 & 21.18 & 1.00 \\
\hline clothianidin consumed & 6.35 & 12.82 & 6.03 & 19.80 & 13.95 & 37.76 & 0.36 \\
\hline cypermethrin consumed & 0.83 & 1.66 & 0.78 & 2.57 & 1.81 & 4.90 & 0.60 \\
\hline difenoconazole consumed & 0.30 & 0.61 & 0.29 & 0.95 & 0.67 & 1.81 & 0.05 \\
\hline fludioxonil consumed & 0.19 & 0.39 & 0.18 & 0.60 & 0.42 & 1.14 & 0.05 \\
\hline flutriafol consumed & 0.41 & 0.82 & 0.39 & 1.27 & 0.90 & 2.42 & 0.03 \\
\hline fluxapyroxad consumed & 0.10 & 0.20 & 0.09 & 0.30 & 0.21 & 0.58 & 0.03 \\
\hline imidacloprid consumed & 62.35 & 125.74 & 59.20 & 194.30 & 136.88 & 370.46 & 1.00 \\
\hline ipconazole consumed & 0.16 & 0.32 & 0.15 & 0.50 & 0.35 & 0.95 & 0.02 \\
\hline metalaxyl consumed & 0.03 & 0.05 & 0.02 & 0.08 & 0.06 & 0.15 & 0.03 \\
\hline penflufen consumed & 0.19 & 0.39 & 0.18 & 0.60 & 0.42 & 1.14 & 0.10 \\
\hline prothioconazole consumed & 0.04 & 0.08 & 0.04 & 0.12 & 0.08 & 0.23 & 0.10 \\
\hline pyraclostrobin consumed & 0.40 & 0.80 & 0.38 & 1.24 & 0.87 & 2.37 & 0.10 \\
\hline sedaxane consume & 0.36 & 0.72 & 0.34 & 1.12 & 0.79 & 2.13 & 0.05 \\
\hline silthiofam consumed & 0.85 & 1.72 & 0.81 & 2.65 & 1.87 & 5.06 & 0.25 \\
\hline tebuconazole consumed & 0.05 & 0.10 & 0.05 & 0.16 & 0.11 & 0.31 & 0.01 \\
\hline tefluthrin consumed & 3.85 & 7.77 & 3.66 & 12.00 & 8.45 & 22.88 & 0.20 \\
\hline thiamethoxam consumed & 4.27 & 8.60 & 4.05 & 13.29 & 9.36 & 25.34 & 0.10 \\
\hline thiram consumed & 0.82 & 1.66 & 0.78 & 2.57 & 1.81 & 4.90 & 1.00 \\
\hline triticonazole consumed & 0.19 & 0.39 & 0.18 & 0.60 & 0.42 & 1.14 & 0.05 \\
\hline
\end{tabular}

Barnham field (Fig. 4). The difference existing between fields could be due to the relatively high number of birds observed on Barnham farm compared to Hartfield fields 1 and 2. On day 0, Barnham was visited by a big flock of corvids (carrion crow, rook, and jackdaw). Our results showed that birds consumed the pesticide-treated seeds left available on the soil surface quickly after being sown, so that most are consumed within about 4 days (Fig. 1). Furthermore, from the camera footage, we discovered that mammals (European badger, Meles meles; wood mouse, Apodemus sylvaticus; and European rabbit, Oryctolagus cuniculus) also participated in the removal of the treated seeds in Hartfield fields. Additionally, some studies have shown the importance of invertebrates, such as ground beetles (Carabidae), on seed predation (weed or crop; Brust and House 1988; Mullin et al. 2005; Talarico et al. 2016).

Out of the 18 bird species observed on the fields, 10 were also observed eating seed in front of the camera traps and 1 species - the feral pigeon-was seen exclusively in front of the camera traps. Species such as chaffinch, magpie, or European robin were exclusively found on boundaries, whereas woodlarks were only observed in front of camera consumed. Only 6 out of our 11 species were available for the estimated daily food intake calculated by Crocker et al. (2002) light grey gradient indicates the highest to lowest percentage of LD50 
the cameras but were observed in the field (supplementary material, Table 1), which may potentially be due to those species being more neophobic, or because bigger species, such as corvids, pheasants, or partridges, monopolising the seeds. We suggest that camera traps are an excellent tool to determine the consumption rate of treated seeds by granivorous birds but that they should not be used in isolation to determine which species feed on treated seeds.

The extrapolation of the dose ingested for other pesticides used as seed treatment, on the base of a worst-case scenario and not considering the palatability differences that may exist between pesticides, showed that the neonicotinoid insecticide imidacloprid is the most likely to cause harm to birds feeding on crop treated seeds, due to its high toxicity (low LD50s, Table 2). The neonicotinoid insecticides clothianidin and thiamethoxam, the pyrethroid insecticide tefluthrin, and the anilide fungicide carboxin also showed a significant toxic potential. This was especially true for the feral pigeon and common chaffinch due to the large amount of seeds ingested per minute compared to their body weight.

Our study and the extrapolation we conducted suggest that if birds ingested seeds treated with imidacloprid at the same consumption rate as with fludioxonil, they would be likely to suffer some direct mortality. This is in accordance with previous studies, which have found that even a small number of imidacloprid-treated seeds could cause sublethal effects or even mortality to some bird species (Mineau and Palmer 2013; Goulson 2013; Gibbons et al. 2015; Eng et al. 2019).

While birds appear unlikely to receive an LD50 of the other pesticides, harmful sublethal effects can occur at much lower doses. For example, signs of toxicity in eared doves (Zenaida auriculata) appear with consumption of only $0.4 \mathrm{~g}$ of imidacloprid-treated sorghum seeds, a tiny fraction of the daily intake (Addy-Orduna et al. 2019). In red munia (Amandava amandava), imidacloprid was shown to impair the hypothalamic-pituitary-thyroid and hypothalamic-pituitary-testicular axis leading to thyrotoxicity and testicular regression at only $0.25 \%$ or $0.5 \%$ of the LD50 (Pandey and Mohanty 2015; Mohanty et al. 2017; Pandey and Mohanty 2017). Eng et al. (2019) showed that consuming less than 5 imidacloprid-treated seeds were sufficient to have negative effects on migration and fat storing in white-crowned sparrows (Zonotrichia leucophrys). Both imidacloprid and clothianidin insecticides have been shown to create reproductive impairment and abnormal behaviour in male quails at much lower doses than their respective LD50s (Northern bobwhite quails (Colinus virginianus): Gibbons et al. 2015; Gobeli et al. 2017; Japanese quail (Coturnix japonica): Tokumoto et al. 2013).

While there has been much research on the effects of insecticides on birds, other pesticides have received little or no attention. Fungicides and herbicides tend to be less acutely toxic to non-target species than insecticides, but are applied in higher quantities than insecticides (Lopez-Antia et al. 2016; Tassin de Montaigu and Goulson 2020). A handful of studies have investigated the effects of seed treatment with fungicides on bird species (McGary et al. 2001; Grote et al. 2008; Satre et al. 2009; Köhler and Triebskorn 2013; Lopez-Antia et al. 2013, 2015, 2018; Pandey and Mohanty 2015; Gross et al. 2020; Ortiz-Santaliestra et al. 2020; Mateo et al. 2016). Thiram was found to reduce egg size, clutch size, number of fertile eggs, and brood size in redlegged partridge (Lopez-Antia et al. 2013, 2015; Pandey and Mohanty 2015). The fungicide difenoconazole also reduced egg size, number of fertile eggs, and the hatching rate in red-legged partridge (Lopez-Antia et al. 2013). The triazole fungicide flutriafol decreased the clutch size and number of fertile eggs and reduced by $50 \%$ the brood size in red-legged partridge (Lopez-Antia et al. 2018). Tebuconazole, another triazole fungicide, increased chick mortality in red-legged partridge when applied as a spray using field-realistic doses (Ortiz-Santaliestra et al. 2020). The dicarboximide fungicide vinclozolin was shown to impact behaviour and social interactions in dark-eyed junco (Junco hyemalis; Satre et al. 2009) and impair male reproductive behaviour in Japanese quail (McGary et al. 2001).

Mateo et al. (2016) found that red-breasted geese were potentially exposed to four fungicides (thiram, tebuconazole, difenoconazole, and fludioxonil) when feeding on germinated winter wheat seeds. By using daily food intake, they estimated the exposure levels of the birds and found that thiram and tebuconazole could represent a risk for geese. Gross et al. (2020) administered realistic quantities of fludioxonil-treated wheat seed to Japanese quails (low dose: $0.0328 \mathrm{mg} / \mathrm{kg}$ b.w, high dose: $0.0985 \mathrm{mg} / \mathrm{kg} \mathrm{b} . \mathrm{w}$ ) and found that fludioxonil did not seem to bioaccumulate in tissues when dosed for 1 or 10 consecutive days. We were unable to find any studies specifically looking at sublethal impacts of the pyrethroid insecticide tefluthrin and the aniline fungicide carboxin on birds. Nonetheless, Millot et al. (2015) and Bro et al. (2016) both found traces of tefluthrin in grey partridge (Perdix perdix) adults and eggs, and Corcellas et al. (2017) found pyrethroid levels in $93 \%$ of wild bird eggs studied, demonstrating that exposure does occur in the wild. Other pyrethroid insecticides have sublethal neurotoxic effects on birds (Sánchez-Bayo 2012), showing behavioural effects in Japanese quail and potentially causing birth defects (David 1982) and inhibiting Japanese quails' liver enzymes (Riviere et al. 1983). No publications studying effects of aniline fungicides on birds were found.

Our study focuses on short-term exposure in a single feeding bout or day. However, the wild birds observed are likely to feed for several days in numerous fields across the landscape, until the surface grain supply has been depleted. Winter wheat sowing is not synchronised across all fields 
of an area and is often sown from September to the end of October. Thus, birds could be exposed to pesticide-treated seeds for several weeks. The effects of such chronic exposure have been little investigated, although significant sublethal effects have been found in red munia after 30 days of exposure to $0.25 \%$ or $0.5 \%$ of the imidacloprid LD50 (Pandey and Mohanty 2015; Pandey and Mohanty 2017; Mohanty et al. 2017) and after 30 days of exposure to $1 \mathrm{mg}$ or $50 \mathrm{mg}$ of clothianidin per kilogramme of body weight in male quail (Tokumoto et al. 2013). Additionally, it is likely for birds to consume seeds coated or sprayed by different pesticides in adjacent fields and/or seeds treated with pesticide mixtures (Green et al. 2005; Köhler and Triebskorn 2013; Milner and Boyd 2017; Dudley et al. 2017; Stanton et al. 2018). Some interactions could occur between those several substances; these could diminish or enhance the toxic effects associated with a single active substance exposure (Larsen et al. 2003; Reffstrup et al. 2010).

A key assumption of our calculation of the doses of pesticides birds may receive from consuming treated seeds is that their palatability would be similar to those treated with fludioxonil. We are not aware of any trial to determine how different pesticide coatings affect seed palatability. Trials have been conducted to compare consumption of treated versus untreated seeds in captivity, and when given the choice birds sometimes show a preference for untreated seeds, depending on what the treatment is (Werner et al. 2010; Pascual et al. 1999b; Bennett and Prince 1981; Avery et al. 1993; Lopez-Antia et al. 2014). Consumption of treated seeds may drop over time as toxic effects begin to manifest, as, for example, occurring in eared doves fed imidacloprid-treated seeds (Addy-Orduna et al. 2019, Avery et al. 1994; LopezAntia et al. 2013; Millot et al. 2017; Botha et al. 2018). Conversely, the repellency of seeds coated with the fungicides thiram and carboxin or pyrethroid insecticides may diminish over time in the absence of alternative food and possibly even form addictive effects (David 1981; Kennedy and Connery 2008; Werner et al. 2010; Lopez-Antia et al. 2014).

Aside from palatability, other factors present in a natural environment such as hunger/starvation (Pascual et al. 1999c), predation risk (Avery et al. 1994), food unpredictability and accessibility (Lopez-Antia et al. 2014; Murton and Visozo 1963; Browns 1968), or competition (McKay et al. 1999) are all likely to influence consumption rates of different bird species in real-world situations. Complex though, all of these effects may be field evidence of bird fatality due to imidacloprid-treated and neonicotinoid-treated seed poisoning has been discovered, showing that wild birds do not always avoid eating treated seeds (Berny et al. 1999; Bro et al. 2004, 2010; Turaga et al. 2016; Millot et al. 2017; Ertl et al. 2018).

In conclusion, our study finds that large quantities of treated seed are left available for wildlife to consume after sowing of winter wheat and that these are consumed by a broad range of farmland bird species. When extrapolated to other pesticides used as seed treatment, this could lead to the ingestion of sufficient pesticide to induce sublethal and lethal effects, particularly following chronic exposure over multiple weeks. Clearly, further work is needed to examine how seed palatability is affected by different seed treatments and how this varies between bird species. Importantly, there is potential for harm from chemicals other than neonicotinoids, which until now have received the bulk of attention.

Supplementary Information The online version contains supplementary material available at https://doi.org/10.1007/s11356-021-17097-y.

Acknowledgements We are very grateful to the farmers for letting us use their fields. We are thankful for the Mammal society to have let us use their camera traps. We are thankful to SongBird Survival, which funded this study.

Author contribution Cannelle Tassin de Montaigu conceived and designed the study, collected data in the field, analysed the data, prepared figures and tables, authored and reviewed drafts of the paper, and approved the final draft.

Prof. Dave Goulson conceived and designed the study, authored and reviewed drafts of the paper, and approved the final draft.

Funding This study was funded by SongBird Survival.

Data Availability The datasets used and/or analysed during the current study are available from the corresponding author on reasonable request.

\section{Declarations}

Ethics approval and consent to participate Not applicable

Consent for publication Not applicable

Competing interests The authors declare no competing interests.

Open Access This article is licensed under a Creative Commons Attribution 4.0 International License, which permits use, sharing, adaptation, distribution and reproduction in any medium or format, as long as you give appropriate credit to the original author(s) and the source, provide a link to the Creative Commons licence, and indicate if changes were made. The images or other third party material in this article are included in the article's Creative Commons licence, unless indicated otherwise in a credit line to the material. If material is not included in the article's Creative Commons licence and your intended use is not permitted by statutory regulation or exceeds the permitted use, you will need to obtain permission directly from the copyright holder. To view a copy of this licence, visit http://creativecommons.org/licenses/by/4.0/.

\section{References}

Addy-Orduna LM, Brodeur JC, Mateo R (2019) Oral acute toxicity of imidacloprid, thiamethoxam and clothianidin in eared doves: 
a contribution for the risk assessment of neonicotinoids in birds. Sci Total Environ 650:1216-1223. https://doi.org/10.1016/j.scito tenv.2018.09.112

Avery, M. L., Decker, D. G., Fischer, D. L., \& Stafford, T. R. (1993). Responses of captive blackbirds to a new insecticidal seed treatment. J Wildl Manag, 652-656. https://doi.org/10.2307/3809296

Avery ML, Decker DG, Fischer DL (1994) Cage and flight pen evaluation of avian repellency and hazard associated with imidaclopridtreated rice seed. Crop Prot 13(7):535-540. https://doi.org/10. 1016/0261-2194(94)90107-4

Avery ML, Fischer DL, Primus TM (1997) Assessing the hazard to granivorous birds feeding on chemically treated seeds. Pestic Sci 49(4):362-366. https://doi.org/10.1002/(SICI)1096-9063(199704) 49:4<362::AID-PS540>3.0.CO;2-W

Bates D, Mächler M, Bolker B, Walker S (2015) Fitting linear mixedeffects models using lme4. J Stat Softw 67(1):1-48. https://doi. org/10.18637/jss.v067.i01

Beauchamp G (1998) The effect of group size on mean food intake rate in birds. Biol Rev 73(4):449-472. https://doi.org/10.1111/j. 1469-185X.1998.tb00179.x

Bennett Jr, R. S., \& Prince, H. H. (1981). Influence of agricultural pesticides on food preference and consumption by ring-necked pheasants. J Wildl Manag, 74-82. https://doi.org/10.2307/38078 75

Berny PJ, Buronfosse F, Videmann B, Buronfosse T (1999) Evaluation of the toxicity of imidacloprid in wild birds. A new high performance thin layer chromatography (HPTLC) method for the analysis of liver and crop samples in suspected poisoning cases. J Liq Chromatogr Relat Technol 22(10):1547-1559. https://doi. org/10.1081/JLC-100101750

Botha CJ, Du Plessis EC, Coetser H, Rosemann M (2018) Analytical confirmation of imidacloprid poisoning in granivorous Cape spurfowl (Pternistis capensis). J S Afr Vet Assoc 89(1):1-5

Bouaziz A, Hicks DR (1990) Consumption of wheat seed reserves during germination and early growth as affected by soil water potential. Plant Soil 128(2):161-165. https://doi.org/10.1007/ BF00011105

Bro E, Terrier ME, Soyez D, Berny P, Reitz F, Gaillet JR (2004) Faut-il $\mathrm{s}$ ' inquiéter de l'état sanitaire des perdrix grises sauvages. Faune Sauvage 261:6-17 (in French)

Bro E, Decors A, Millot F, Soyez D, Moinet M (2010) Intoxications des perdrix grises en nature. Nouveau bilan de la surveillance « SAGIR ». Faune Sauvage 289:26-32 (in French)

Bro E, Devillers J, Millot F, Decors A (2016) Residues of plant protection products in grey partridge eggs in French cereal ecosystems. Environ Sci Pollut Res 23(10):9559-9573. https://doi.org/10. 1007/s11356-016-6093-7

Browne SJ, Aebischer NJ (2003) Habitat use, foraging ecology and diet of Turtle Doves Streptopelia turtur in Britain. Ibis 145(4):572582. https://doi.org/10.1046/j.1474-919X.20003.00185.x

Browns RGB (1968) Seed selection by pigeons. Behaviour 34:115-131

Brust GE, House GJ (1988) Weed seed destruction by arthropods and rodents in low-input soybean agroecosystems. Am J Altern Agric $3(1): 19-25$

Chamberlain DE (2002) Effects of agricultural intensification on birds: evidence from monitoring data. Asp Appl Biol 67:1-10

Corcellas C, Andreu A, Máñez M, Sergio F, Hiraldo F, Eljarrat E, Barceló D (2017) Pyrethroid insecticides in wild bird eggs from a World Heritage Listed Park: a case study in Doñana National Park (Spain). Environ Pollut 228:321-330. https://doi.org/10.1016/j. envpol.2017.05.035

Crocker D, Hart A, Gurney J, McCoy C (2002) Methods for estimating daily food intake of wild birds and mammals. Central science laboratory science serving agriculture, food and the environment
David D (1981) Laboratory evaluation of repellent properties against birds of the synthetic pyrethroid decamethrin. Poult Sci 60(6):1149-1151

David D (1982) Influence of technical and commercial decamethrin, a new synthetic pyrethroid, on the gonadic germ population in Quail embryos. Archives d'anatomie, d'histologie et d'embryologie normales et experimentales 65:99-110

De Snoo GR, Scheidegger NM, de Jong FM (1999) Vertebrate wildlife incidents with pesticides: a European survey. Pestic Sci 55(1):4754. https://doi.org/10.1002/(SICI)1096-9063(199901)55:1<47:: AID-PS859>3.0.CO;2-\%23

De Snoo GR, Luttik R (2004) Availability of pesticide-treated seed on arable fields. Pest Management Science: formerly Pesticide Science 60(5):501-506. https://doi.org/10.1002/ps.824

Dewar AM, Asher MJC (1994) A European perspective on pesticide seed treatments in sugar beet. Pesticide Outlook 5(3):11-11

Dudley N, Attwood SJ, Goulson D, Jarvis D, Bharucha ZP, Pretty J (2017) How should conservationists respond to pesticides as a driver of biodiversity loss in agroecosystems? Biol Conserv 209:449-453

Edwards, P. J., Bembridge, J., Jackson, D., Earl, M., \& Anderson, L. (1998, April). Estimation of pesticides residues on weed seeds for wildlife risk assessment. In Proceedings (pp. 14-18).

Eng ML, Stutchbury BJ, Morrissey CA (2019) A neonicotinoid insecticide reduces fueling and delays migration in songbirds. Science 365(6458):1177-1180. https://doi.org/10.1126/science.aaw9419

Ertl HM, Mora MA, Boellstorff DE, Brightsmith D, Carson K (2018) Potential effects of neonicotinoid insecticides on northern bobwhites. Wildl Soc Bull 42(4):649-655. https://doi.org/10.1002/ wsb. 921

Geiger F, Bengtsson J, Berendse F, Weisser WW, Emmerson M, Morales MB, Inchausti P (2010) Persistent negative effects of pesticides on biodiversity and biological control potential on European farmland. Basic and Applied Ecology 11(2):97-105. https://doi.org/10.1016/j.baae.2009.12.001

Gibbons D, Morrissey C, Mineau P (2015) A review of the direct and indirect effects of neonicotinoids and fipronil on vertebrate wildlife. Environ Sci Pollut Res 22(1):103-118. https://doi.org/10. 1007/s11356-014-3180-5

Gobeli A, Crossley D II, Johnson J, Reyna K (2017) The effects of neonicotinoid exposure on embryonic development and organ mass in northern bobwhite quail (Colinus virginianus). Comparative Biochemistry and Physiology Part C: Toxicology \& Pharmacology 195:9-15. https://doi.org/10.1016/j.cbpc.2017.02.001

Goulson D (2013) An overview of the environmental risks posed by neonicotinoid insecticides. J Appl Ecol 50(4):977-987. https:// doi.org/10.1111/1365-2664.12111

Green RE, Cornell SJ, Scharlemann JP, Balmford A (2005) Farming and the fate of wild nature. Science 307(5709):550-555

Gross MS, Bean TG, Hladik ML, Rattner BA, Kuivila KM (2020) Uptake, metabolism, and elimination of fungicides from coated wheat seeds in Japanese quail (Coturnix japonica). J Agric Food Chem 68(6): 1514-1524

Grote K, Niemann L, Selzsam B, Haider W, Gericke C, Herzler M, Chahoud I (2008) Epoxiconazole causes changes in testicular histology and sperm production in the Japanese quail (Coturnix coturnix japonica). Environmental Toxicology and Chemistry: An International Journal 27(11):2368-2374. https://doi.org/10. 1897/08-048.1

Hallmann CA, Foppen RP, Van Turnhout CA, De Kroon H, Jongejans E (2014) Declines in insectivorous birds are associated with high neonicotinoid concentrations. Nature 511(7509):341-343. https:// doi.org/10.1038/nature13531

Hart, A. D. M., \& Clook, M. A. (1994). Research based improvements in the regulation of hazards to wildlife from pesticide seed treatments. Monographs-British Crop Protection Council, 449-449. 
Holland JM, Hutchison MAS, Smith B, Aebischer NJ (2006) A review of invertebrates and seed-bearing plants as food for farmland birds in Europe. Ann Appl Biol 148(1):49-71

Kennedy TF, Connery J (2008) An investigation of seed treatments for the control of crow damage to newly-sown wheat. Irish J Agric Food Res, 79-91.

Köhler HR, Triebskorn R (2013) Wildlife ecotoxicology of pesticides: can we track effects to the population level and beyond? Science 341(6147):759-765

Larsen JC, Binderup M-L, Dalgaard M, Dragsted LO, Hossaini A, Ladefoged O,Lam HR, Madsen C, Meyer O, Rasmussen ES, Reffstrup TK, Søborg I,Vinggaard AM, Østergård G (2003) Combined actions and interactions ofchemicals in mixtures. The toxicological effects of exposure to mixtures ofindustrial and environmental chemicals. In: Larsen, J.C. (Ed.). Danish Veterinaryand Food Administration. FødevareRapport 12

Lennon RJ, Peach WJ, Dunn JC, Shore RF, Pereira MG, Sleep D et al (2020a) From seeds to plasma: Confirmed exposure of multiple farmland bird species to clothianidin during sowing of winter cereals. Sci Total Environ 723:138056. https://doi.org/10.1016/j. scitotenv.2020.138056

Lennon RJ, Shore RF, Pereira MG, Peach WJ, Dunn JC, Arnold KE, Brown CD (2020b) High prevalence of the neonicotinoid clothianidin in liver and plasma samples collected from gamebirds during autumn sowing. Sci Total Environ 742:140493

Lopez-Antia A, Ortiz-Santaliestra ME, Mougeot F, Mateo R (2013) Experimental exposure of red-legged partridges (Alectoris rufa) to seeds coated with imidacloprid, thiram and difenoconazole. Ecotoxicology 22(1):125-138. https://doi.org/10.1007/ s10646-012-1009-x

Lopez-Antia A, Ortiz-Santaliestra ME, Mateo R (2014) Experimental approaches to test pesticide-treated seed avoidance by birds under a simulated diversification of food sources. Sci Total Environ 496:179-187. https://doi.org/10.1016/j.scitotenv.2014.07.031

Lopez-Antia A, Ortiz-Santaliestra ME, Blas EGD, Camarero PR, Mougeot F, Mateo R (2015) Adverse effects of thiram-treated seed ingestion on the reproductive performance and the offspring immune function of the red-legged partridge. Environ Toxicol Chem 34(6):1320-1329

Lopez-Antia A, Feliu J, Camarero PR, Ortiz-Santaliestra ME, Mateo $\mathrm{R}$ (2016) Risk assessment of pesticide seed treatment for farmland birds using refined field data. J Appl Ecol 53(5):1373-1381. https://doi.org/10.1111/1365-2664.12668

Lopez-Antia A, Ortiz-Santaliestra ME, Mougeot F, Camarero PR, Mateo R (2018) Brood size is reduced by half in birds feeding on flutriafol-treated seeds below the recommended application rate. Environ Pollut 243:418-426. https://doi.org/10.1016/j.envpol. 2018.08.078

MacDonald AM, Jardine CM, Thomas PJ, Nemeth NM (2018) Neonicotinoid detection in wild turkeys (Meleagris gallopavo silvestris) in Ontario, Canada. Environ Sci Pollut Res 25(16):16254-16260

Mateo R, Petkov N, Lopez-Antia A, Rodríguez-Estival J, Green AJ (2016) Risk assessment of lead poisoning and pesticide exposure in the declining population of red-breasted goose (Branta ruficollis) wintering in Eastern Europe. Environ Res 151:359-367

McGary S, Henry PF, Ottinger MA (2001) Impact of vinclozolin on reproductive behavior and endocrinology in Japanese quail (Coturnix coturnix japonica). Environ Toxicol Chem: Int $\mathrm{J}$ 20(11):2487-2493

McGee S, Whitfield-Aslund M, Duca D, Kopysh N, Dan T, Knopper L, Brewer L (2018) Field evaluation of the potential for avian exposure to clothianidin following the planting of clothianidin-treated corn seed. PeerJ 6:e5880. https://doi.org/10.7717/peerj.5880

McKay HV, Prosser PJ, Hart ADM, Langton SD, Jones A, McCoy C, ... \& Pascual JA (1999) Do wood-pigeons avoid pesticide-treated cereal seed?. J Appl Ecol, 36(2), 283-296. https://doi.org/10. 1046/j.1365-2664.1999.00398.x

Millot F, Berny P, Decors A, Bro E (2015) Little field evidence of direct acute and short-term effects of current pesticides on the grey partridge. Ecotoxicol Environ Saf 117:41-61. https://doi.org/ 10.1016/j.ecoenv.2015.03.017

Millot F, Decors A, Mastain O, Quintaine T, Berny P, Vey D, Bro E (2017) Field evidence of bird poisonings by imidacloprid-treated seeds: a review of incidents reported by the French SAGIR network from 1995 to 2014. Environ Sci Pollut Res 24(6):54695485. https://doi.org/10.1007/s11356-016-8272-y

Milner AM, Boyd IL (2017) Toward pesticidovigilance. Science 357(6357):1232-1234

Mineau P, Collins BT, Baril A (1996) On the use of scaling factors to improve interspecies extrapolation of acute toxicity in birds. Regul Toxicol Pharmacol 24(1):24-29. https://doi.org/10.1006/ rtph.1996.0061

Mineau P, Baril A, Collins BT, Duffe J, Joerman G, Luttik R (2001) Pesticide acute toxicity reference values for birds. Rev Environ Contam Toxicol 170:13-74

Mineau P, Palmer C (2013) The impact of the nation's most widely used insecticides on birds. American Bird Conservancy

Mohanty B, Pandey SP, Tsutsui K (2017) Thyroid disrupting pesticides impair the hypothalamic-pituitary-testicular axis of a wildlife bird, Amandava amandava. Reprod Toxicol 71:32-41. https://doi.org/10.1016/j.reprotox.2017.04.006

Mullin CA, Saunders MC, Leslie TW, Biddinger DJ, Fleischer SJ (2005) Toxic and behavioral effects to Carabidae of seed treatments used on Cry3Bb1-and Cry $1 \mathrm{Ab} / \mathrm{c}$-protected corn. Environ Entomol 34(6):1626-1636

Murton RK, Visozo M (1963) Dressed cereal seed as a hazard to wood-pigeons. Ann Appl Biol 52(3):503-517. https://doi.org/ 10.1111/j.1744-7348.1963.tb03773.x

Ortiz-Santaliestra ME, Alcaide V, Camarero PR, Mateo R, Mougeot F (2020) Egg overspray with herbicides and fungicides reduces survival of red-legged partridge chicks. Environ Sci Technol 54(19):12402-12411

Pandey SP, Mohanty B (2015) The neonicotinoid pesticide imidacloprid and the dithiocarbamate fungicide mancozeb disrupt the pituitary-thyroid axis of a wildlife bird. Chemosphere 122:227234. https://doi.org/10.1016/j.chemosphere.2014.11.061

Pandey SP, Mohanty B (2017) Disruption of the hypothalamicpituitary-thyroid axis on co-exposures to dithiocarbamate and neonicotinoid pesticides: Study in a wildlife bird, Amandava amandava. Neurotoxicology 60:16-22. https://doi.org/10.1016/j. neuro.2017.02.010

Pascual JA, Hart ADM, Saunders PJ, McKay HV, Kilpatrick J, Prosser P (1999a) Agricultural methods to reduce the risk to birds from cereal seed treatments on fenlands in eastern England. I. Sowing depth manipulation. Agric Ecosyst Environ 72(1):59-73. https://doi.org/10.1016/S0167-8809(98)00163-7

Pascual JA, Hart AD, Fryday SL (1999b) Incidence of lethal bird poisoning reduced by regurgitation of pesticide-treated food. Environ Toxicol Chem: An Int J 18(2):247-253. https://doi.org/ 10.1002/etc.5620180222

Pascual JA, Fryday SL, Hart ADM (1999c) Effects of food restriction on food avoidance and risk of acute poisoning of captive feral pigeons from fonofos-treated seeds. Arch Environ Contam Toxicol 37(1):115-124. https://doi.org/10.1007/s002449900496

PPDB: Pesticide Properties DataBase (2021) University of Hertfordshire. http://sitem.herts.ac.uk/aeru/ppdb/

Perkins AJ, Anderson G, Wilson JD (2007) Seed food preferences of granivorous farmland passerines. Bird Study 54(1):46-53. https://doi.org/10.1080/00063650709461455

Potts GR, Aebischer NJ (1995) Population dynamics of the Grey Partridge Perdix perdix 1793-1993: monitoring, modelling and 
management. Ibis 137:S29-S37. https://doi.org/10.1111/j.1474919X.1995.tb08454.x

Porter RER (1977) Methiocarb protects sprouting peas from small birds. N Z J Exp Agric 5(4):335-338. https://doi.org/10.1080/ 03015521.1977 .10425992

Prosser P, Hart ADM (2005) Assessing potential exposure of birds to pesticide-treated seeds. Ecotoxicology 14(7):679-691. https:// doi.org/10.1007/s10646-005-0018-4

Core Team R (2020) R: A language and environment for statistical computing. In: R Foundation for Statistical Computing. Austria. URL, Vienna https://www.R-project.org/

Reffstrup TK, Larsen JC, Meyer O (2010) Risk assessment of mixtures of pesticides. Current approaches and future strategies. Regul Toxicol Pharmacol 56(2):174-192

Riviere JL, Bach J, Grolleau G (1983) Effect of pyrethroid insecticides and $\mathrm{N}-(3,5$-dichlorophenyl) dicarboximide fungicides on microsomal drug-metabolizing enzymes in the Japanese quail (Coturnix coturnix). Bull Environ Contam Toxicol 31(4):479-485

Robinson RA (2004) The diet of seed-eating birds on lowland farmland. British Birds 97(9):464-467

Roy CL, Coy PL, Chen D, Ponder J, Jankowski M (2019) Multi-scale availability of neonicotinoid-treated seed for wildlife in an agricultural landscape during spring planting. Sci Total Environ 682:271-281. https://doi.org/10.1016/j.scitotenv.2019.05.010

Sánchez-Bayo F (2012) Insecticides mode of action in relation to their toxicity to non-target organisms. J Environ Anal Toxicol S 4:S4-S002

Satre D, Reichert M, Corbitt C (2009) Effects of vinclozolin, an antiandrogen, on affiliative behavior in the Dark-eyed Junco, Junco hyemalis. Environ Res 109(4):400-404

Stanton RL, Morrissey CA, Clark RG (2018) Analysis of trends and agricultural drivers of farmland bird declines in North America: A review. Agric Ecosyst Environ 254:244-254

Talarico F, Giglio A, Pizzolotto R, Brandmayr P (2016) A synthesis of feeding habits and reproduction rhythm in Italian seed-feeding ground beetles (Coleoptera: Carabidae). EJE 113(1):325-336
Tassin de Montaigu C, Goulson D (2020) Identifying agricultural pesticides that may pose a risk for birds. PeerJ 8:e9526. https://doi. org/10.7717/peerj.9526

Tokumoto J, Danjo M, Kobayashi Y, Kinoshita K, Omotehara T, Tatsumi A, Hoshi N (2013) Effects of exposure to clothianidin on the reproductive system of male quails. J Vet Med Sci:12-0544. https://doi.org/10.1292/jvms.12-0544

Turaga U, Peper ST, Dunham NR, Kumar N, Kistler W, Almas S, Kendall RJ (2016) A survey of neonicotinoid use and potential exposure to northern bobwhite (Colinus virginianus) and scaled quail (Callipepla squamata) in the Rolling Plains of Texas and Oklahoma. Environ Toxicol Chem 35(6):1511-1515. https://doi. org/10.1002/etc.3305

Watkinson AR, Freckleton RP, Robinson RA, Sutherland WJ (2000) Predictions of biodiversity response to genetically modified herbicide-tolerant crops. Science 289(5484):1554-1557. https://doi. org/10.1126/science.289.5484.1554

Werner SJ, Linz GM, Tupper SK, Carlson JC (2010) Laboratory efficacy of chemical repellents for reducing blackbird damage in rice and sunflower crops. J Wildl Manag 74(6):1400-1404. https://doi. org/10.1111/j.1937-2817.2010.tb01264.X

Wilson JD, Morris AJ, Arroyo BE, Clark SC, Bradbury RB (1999) A review of the abundance and diversity of invertebrate and plant foods of granivorous birds in northern Europe in relation to agricultural change. Agric Ecosyst Environ 75(1-2):13-30. https://doi. org/10.1016/S0167-8809(99)00064-X

Publisher's note Springer Nature remains neutral with regard to jurisdictional claims in published maps and institutional affiliations. 